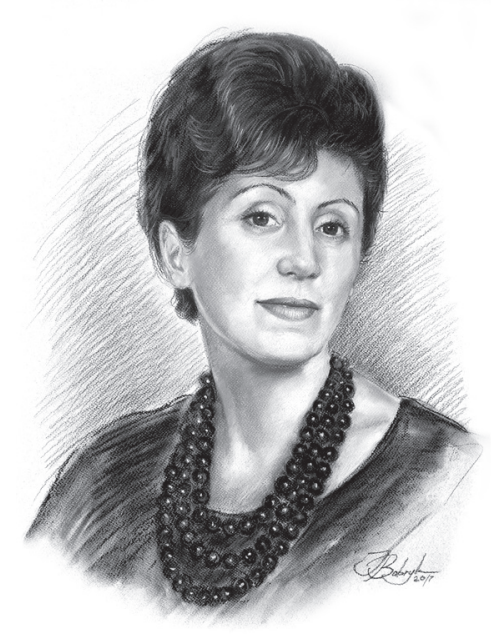

\title{
Profesor Stefania Jabłońska we wspomnieniach
}

\begin{abstract}
Pani Profesor Stefania Jabłońska nauczyła nas, że wszyscy mówimy uniwersalnym językiem dermatologii
\end{abstract}

Profesor Stefania Jabłońska była wielkim, międzynarodowym dermatologiem o ogromnej charyzmie. Nazwisko i osiągnięcia Pani Profesor sprawiały, że do Kliniki Dermatologicznej Akademii Medycznej w Warszawie przy ul. Koszykowej 82 A przyjeżdżali dermatolodzy z całego świata. Niektórzy przybywali z odległych krajów, aby uczyć się w jednym z najlepszych ośrodków dermatologicznych na świecie, inni byli osobistymi gośćmi i przyjaciółmi prof. Jabłońskiej.

Dziś wielu znakomitych dermatologów wspomina chwile kontaktów z prof. Jabłońską. Na moje ręce do Polskiego Towarzystwa Dermatologicznego i do Kliniki Dermatologicznej Warszawskiego Uniwersytetu Medycznego wpłynęło mnóstwo listów ze wspomnieniami i kondolencjami z całego świata.

Jeden z bliskich przyjaciół prof. Jabłońskiej, prof. Stephen I. Katz, dyrektor National Institute of Arthritis and Musculoskeletal and Skin NIH (USA), przypomnial, jak prof. Stefania Jabłońska łamała bariery utrudniające awans naukowy osobom z Polski i lekarzom kobietom. Profesor Katz napisal:

I had been very close to her and admired her greatly. She was an inspiration for those of us who have spent our lives in dermatology. She was also an inspiration for women in dermatology in that she broke many barriers through her prominence in international organizational as well as scientific dermatology. Indeed, she did not restrict herself to dermatological pursuits but was also highly respected as a virologist.

I believe that she opened many doors for young scientists from eastern Europe, particularly from Poland. These open doors have made the world a small place and, as a consequence, people with all kinds of skin conditions have improved their quality of life because of the interactions that have taken place. This happened long before the age of rapid transfer of information through new technology.

Profesor Otto Braun-Falco, autor słynnego podręcznika dermatologii, opisal, jak poznał prof. Jabłońską w Wiedniu. Wspominał też wspólne chwile od czasów ich młodości. Przypomniał, że prof. Stefania Jabłońska prezentowała wybitnym dermatologicznym gościom z zagranicy przypadki pacjentów Kliniki i prosiła o opinię na temat rozpoznania lub leczenia. Dla wielu gości było to największe wyzwanie wizyty w Polsce:

Stefania was my best dermatological friend. Having meet her in the fifties of the last century during a dermatology congress in Vienna she held an impressing lecture about her scientific results about the histochemistry of connective tissue around different types skin ulcers making me interested to meet her and getting into contact. Over a period of several international congresses we have met again and again and over years a highly solid friendship 
developed based on mutual respect towards clinical and scientific excellence. Our friendship even became more intensified when both of us were elected as members of the International League of Dermatological Societies ILDS.

During this period I was invited by Stefania to visit her department in Warschau which turned out to become an unforgettable dermatological event. She invited about 20 of her special patients suffering from difficult to diagnose and difficult to treat chronic dermatoses. Those patients provide the fundus for intensive discussions about the clinical spectrum of certain dermatoses as well as the limitation of treatment during that time. Moreover these case presentations allowed to recognize the intense and immense knowlegde in dermatology Stefania Jablonska accumulated in her career. At the same time the visiting guest doctor was challenged to come along with her excellence.

With Stefania Jablonska I lose my best and highly respected friend in dermatology which I will always remember.

Profesor Harvey Lui (Kanada), prezes International League of Dermatological Societies, wspominał niezwykłe życie prof. Stefanii Jabłońskiej i jej rolę w budowaniu porozumień ponad podziałami. Przypomniał, że była aktywnym członkiem League of Dermatological Societies i pierwszą w historii kobietą w zarządzie tej organizacji:

Prof. Stefania Jablonska led an extraordinary life and was a trailblazer at many levels including her unique and enduring contributions to patient care, research, and education in dermatology. It has been observed by many that Prof. Jablonska paved the way for women to assume leading roles in our specialty, but I also believe that she set a remarkable example for all of us to follow as dermatologists - young and old, women and men. Her career was marked by meticulous clinical observation and the uncompromising pursuit of truth through research.

Prof. Jablonska gained an international reputation for excellence and brought tremendous prestige and recognition to the Polish dermatology community that continues to this day. Nowadays we take globalization and instantaneous communications for granted, but there was a time not so long ago when dermatologists from the east and west were not able to reach each other. Prof. Jablonska served as a vital human bridge between these separate worlds, and taught us that we all speak through the universal language of dermatology regardless of where we live or practice. Her election and contributions to the ILDS's International Committee of Dermatology in the 1960's heralded the transition of the ILDS towards being more globally inclusive.

Those who had the good fortune to interact directly with her will never forget her wisdom, tenacity, and kindness, while future generations will continue to benefit from her many observations and discoveries.
Profesor Henry W. Lim (USA), prezes Amerykańskiej Akademii Dermatologii, zwrócił uwagę, że prof. Stefania Jabłońska bardzo lubiła dzielić się swoją wiedzą dermatologiczną z innymi:

Stefania was truly a remarkable woman; a diligent, inquisitive dermatologist, researcher, clinician, educator, mentor and colleague. She was among the first woman leaders in dermatology and made significant contributions especially in the study of bullous diseases and sclerodermoid skin diseases.

In addition, Stefania was an active leader in international dermatology. She had tremendous energy and compassion and always willing to share her knowledge and expertise.

Prezes Niemieckiego Towarzystwa Dermatologicznego prof. Leena Bruckner-Tuderman (Niemcy) pisała m.in. o roli prof. Stefani Jabłońskiej w budowaniu współpracy międzynarodowej:

Professor Stefania Jablonska, one of the giants of worldwide dermatology. We knew prof. Stefania Jablonska was not only an outstanding clinician and an excellent scientist, but also an engaged mediator of international collaboration and exchange in dermatology over an remarkably long time. She was a Honorary Member of the German Dermatological Society for more than 50 years.

Pisząc w imieniu Austriackiego Towarzystwa Dermatologicznego, profesorowie Matthias Schmuth, Peter Fritsch, Klaus Wolff (Austria) zwrócili uwage na ciekawość świata prof. Jabłońskiej i jej umiejętność rozwiązywania problemów o fundamentalnym znaczeniu dla rozumienia chorób skóry:

The Austrian Society of Dermatology and Venereology mourns the loss of its honorary member, Professor Stefania Jablonska, who was a dear friend and dedicated physician scientist.

She traversed boundaries, both scientifically and culturally. She pioneered the use of concepts from the fields of virology and immunology to tackle fundamental questions of skin pathology. For her achievements she received honorary membership and the highest honor of our society, the gold medal, in 1999.

Prof. Jablonska was a rigorous educator and a role model for us all. She was influential on the international stage of dermatology.

Her innate curiosity and appreciation of life will remain with those who were fortunate to be her friend. We will remember her for her enthusiasm, open-mindedness, and loyalty to her friends and institutions.

Prezes European Society of Dermatologic Research prof. Matthias Schmuth podkreśla zdolność prof. Stefanii Jabłońskiej do innowacyjnego myślenia 
i umiejętność przekonywania innych do swoich poglądów:

The community of European skin scientists will dearly miss Professor Jablonska. She received a very impressive number of awards and honors by many national professional societies. She was also honorary member of our international organization, the European Society of Dermatologic Research (ESDR). As representatives of the ESDR, promoting skin research in all of Europe, the board of the ESDR expresses deep gratitude for all she has done for skin research.

Professor Jablonska will be remembered as an innovative thinker, a promoter of research and a friend for many. Her interests were broad, she was a formidable debater. From early in her career she was determined to excel in research and what we today call translational medicine. Her achievements, for example in studying HPV infections or cutaneous autoimmunity among many other subjects, are deeply appreciated in Europe and throughout the world. Prof. Jablonska is certainly one of the most respected, quoted and liked European dermatologists. Her legacy will live on through generations.

Prezes European Academy of Dermatology and Venereology prof. Luca Borradori (Szwajcaria) i sekretarz generalny dr Michael Reusch (Niemcy) zwrócili uwagę, że prof. Jabłońska dawała niezwykły przykład poświęcenia dla swojej pracy i pasji:

In 2013, the Academy granted prof. Stefania Jablonska the Honorary Membership in recognition of her long standing partnership and to officially recognise her many achievements. During her entire professional career, Professor Jablonska enthusiastically promoted our specialty and was an extraordinary example of dedication to and passion for her work.

We will cherish her memory with respect and gratitude, feeling privileged for having had possibility of knowing such a person.

Laurent Degos (Francja) pisał o przyjaźni prof. Stefanii Jabłońskiej z jego ojcem Robertem Degosem, który jako pierwszy zidentyfikował malignant atrophic papulosis (chorobę Degosa). Wspominał, że zarówno prof. Jabłońska, jak i prof. Degos bardzo cenili w sobie nawzajem niezwykłą inteligencję:

The close friendship between Stephanie Jablonska and our parents Robert and Monique Degos in Paris began 60 years ago and was permanently vivified thanks to scientific meetings, travels, and frequent letters by postmail until the deaths of Robert in 1987 and Monique 12 years later.

Stephanie Jablonska and our father Robert Degos experienced a reciprocal esteem and admiration exerting their skills to diagnose patients. They liked to challenge their talents like partners of a game, a game for the benefit of the patients.
She was considered as our Polish mother encouraging us in our scholarship and giving us gifts at Christmas contrasting with her self-controlled attitude and her authority when she chaired scientific sessions of meetings.

Profesorowie Takashi Hashimoto i Takeji Nishikawa (Japonia) podkreślali rolę prof. Jabłońskiej w rozwoju immunodermatologii i budowaniu współpracy polsko-japońskiej:

We have known prof. Stefania Jablonska for years and have learned a lot from her, mainly through problems in immunodermatology. She was a great leader of dermatology representing not only Poland but whole Europe. We do hope that many bonds and bridges built up between Polish and Japanese dermatology will live on and continue to develop long.

Przewodniczący komitetu międzynarodowego Chilijskiego Towarzystwa Dermatologicznego prof. Raul Cabrera (Chile) podkreślił, jak bardzo znane są osiągnięcia prof. Stefanii Jabłońskiej dermatologom w Chile:

Prof. Stefania Jablonska's contribution to the progress of immunodermatology will always be remembered by Chilean Dermatologists.

Profesor Jose M. Mascaro z Barcelony (Hiszpania) stwierdził, że prof. Stefania Jabłońska była osobą o unikatowej inteligencji, erudycji, wytrwałości i rozsądku:

Prof. Stefania Jablonska has been one of the most leading Masters of contemporaneous dermatology. It is not possible in a few words to summarize her impact in international dermatology. She was really a woman of exceptional talent and determination and a unique example of intelligence, erudition, perseverance and judgment. I had the privilege to know her since the time, in the early sixties. I trained in St Louis Hospital of Paris where she was deeply admired. She gave me always the best advices and distinguished me with her friendship.

Laureat Nagrody Nobla prof. Harald zur Hausen (Niemcy), który przez wiele lat współpracował z prof. Stefanią Jabłońską, zwrócił uwagę na pionierskie badania prof. Jabłońskiej nad onkogenną rolą wirusów HPV:

Over several decades we have been in close contact with Stefania and consider her death as a tragic loss for the large number of her friends and for the international dermatological and virological societies and colleagues.

Stefania Jablonska represented one of the limited number of scientists with profound interest in basic and clinical aspects of her field. We were particularly fond of her keen interest in epidermodysplasia verruciformis, with a large number of pioneering discoveries by herself and her group.

We feel deep sympathy with members of her family and the large number of colleagues with whom she cooperated 
and who have been trained by her. The active and engaged contributions of Stefania to meetings and to scientific topics will be missed by everyone who had a chance to become acquainted with her.

Profesor John Hunter z Edynburga (Wielka Brytania) podkreślał, jak istotną rolę odegrała prof. Stefania Jabłońska dla prestiżu polskiej nauki na świecie:

Stefania. A visionary lady, the heroine of hundreds of dermatologists scattered all over the globe, including little Scotland! Highly intelligent and remarkably pragmatic, she flew the flag of Poland and of her Department in Warsaw during the dark times and beyond. She was a great leader and a hostess without pomp; she was wonderfully engaging. How she will be missed, but we must celebrate her amazing life and be grateful that we knew her as a colleague and dear friend.

Polscy dermatolodzy i uczniowie prof. Jabłońskiej, którzy wyjechali z Polski i odnoszą sukcesy w innych krajach, zawsze chętnie utrzymywali kontakt z naszą Kliniką i prof. Jabłońską. Jednym z nich jest prof. Tomasz Mroczkowski (USA), który napisał m.in.:

Miałem zaszczyt gościć prof. Jabłońska w Nowym Orleanie, gdzie na Jej wykłady zjeżdżali się dermatolodzy nie tylko z naszego miasta, ale z catej Luizjany i innych stanów USA.
Profesor Marek Haftek (Francja) napisał:

Kochana Pani Profesor "Ty jesteś jak zdrowie. Ile Cie trzeba cenić, ten tylko się dowie, kto Cię stracit". Żałuje, że sie już więcej nie spotkamy.

Wielu profesorów dermatologii zwraca uwagę, że prof. Stefania Jabłońska była nie tylko wybitnym naukowcem, lecz także pełnym uroku i wdzięku, cieszącym się życiem człowiekiem. Profesor Raul Cabrera (Chile) napisał:

Her friendly nature and enthusiastic personality will remain in our hearts.

Profesor Ana Kaminsky (Argentyna) przypominała jedno ze spotkań w Nowym Jorku, gdy obserwowała jak pięknie prof. Jabłońska wtedy tańczyła:

I will never forget when, in 1992, at the time of the World Congress of Dermatology which took place in New York, I enjoyed seeing her dancing at the Rainbow Room of the Rockefeller Center.

Listy na moje ręce nadesłali również profesorowie Jorge Ocampo (Meksyk), Thomas Krieg (Niemcy), Walter Gebhart (Austria), Jerry Shapiro (USA) i wielu innych wybitnych dermatologów z całego świata.

Autorzy tych listów wskazują, że niezwykłe międzynarodowe życie prof. Stefanii Jabłońskiej nie przestaje być inspiracją dla współczesnych dermatologów wielu krajów świata, a liczne osiągnięcia naukowe będą miały znaczenie ponadczasowe.

prof. dr hab. n. med. Lidia Rudnicka prezes Polskiego Towarzystwa Dermatologicznego 


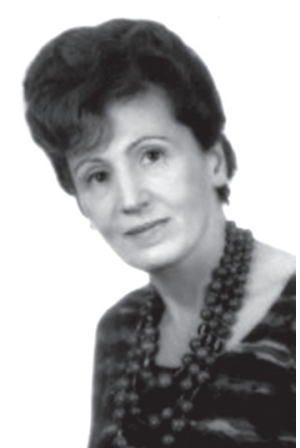

\section{Profesor dr hab. med. Stefania Jabłońska (1920-2017)}

8 maja 2017 r. zmarła prof. dr hab. med. Stefania Jabłońska, wybitny dermatolog i naukowiec, wieloletni kierownik warszawskiej Kliniki Dermatologicznej i prezes Polskiego Towarzystwa Dermatologicznego, wychowawca wielu pokoleń lekarzy, dla których była nauczycielem i mistrzem. Pogrzeb Pani Profesor odbył się na Cmentarzu Wojskowym na warszawskich Powązkach. Uczestniczyła w nim najbliższa rodzina, przyjaciele, liczni uczniowie, kierownicy lub przedstawiciele wszystkich polskich klinik dermatologicznych. Śmierć prof. Stefanii Jabłońskiej odbiła się także szerokim echem wśród światowych dermatologów. Na ręce prof. Lidii Rudnickiej, przewodniczącej PTD, wpłynęło wiele listów z wyrazami głębokiego żalu, a prof. Gerard Orth z Instytutu Pasteura w Paryżu i prof. Thomas Krieg, kierownik Kliniki Dermatologicznej w Kolonii, przyjechali specjalnie do Warszawy, aby osobiście pożegnać pierwszą damę polskiej dermatologii.

Profesor Stefania Jabłońska urodziła się 7 września 1920 r. w Warszawie. Ojciec, Emil Ginsburg był ekonomistą, natomiast matka, Bella - lekarzem dermatologiem. Naukę w gimnazjum Zjednoczenia Nauczycieli rozpoczęła w wieku 6 lat (1926 r.), a świadectwo maturalne uzyskała, mając lat 17 (1937 r.), i w tym samym roku podjęła studia lekarskie. Po wybuchu wojny kontynuowała naukę na Uniwersytecie Lwowskim, a następnie we Frunze (stolica Kirgistanu). W 1942 r. uzyskała dyplom lekarski, z wyróżnieniem, i została wysłana w szeregach Armii Radzieckiej na front. Ciężko ranna w bitwie pod Kurskiem odbywała długą rehabilitację (m.in. w Leningradzie), podczas której ukończyła studia podyplomowe w dziedzinie patologii (pod kierunkiem prof. Olgi Podwysockiej), przygotowała pracę doktorską dotyczącą histopatologii odczynów skórnych na tuberkulinę i wyciągi z prątka gruźlicy oraz zrobiła specjalizację z dermatologii i wenerologii. Po powrocie do Polski rozpoczęła w 1946 r. pracę w warszawskiej Klinice Dermatologicznej kie- rowanej przez prof. Mariana Grzybowskiego. W tym czasie, oprócz pracy klinicznej, przygotowywała swoją pracę habilitacyjną. Wiadomość o aresztowaniu i śmierci prof. Grzybowskiego zastała prof. Jabłońską w Filadelfii, gdzie przebywała na stypendium WHO. Natychmiast wróciła do Warszawy i wtedy powierzono jej obowiązki zastępcy kierownika Kliniki, natomiast na stanowisko kierownika powołano ją w 1952 r. W ciągu tych 3 lat (1949-1952) obroniła w 1950 r. pracę doktorską, a w 1951 r. uzyskała stopień doktora habilitowanego na podstawie pracy pt. „Odczynowość skóry w gruźlicy i sarkoidozie". Praca ta była wcześniej referowana na pierwszym powojennym Zjeździe PTD, który odbył się w Warszawie w czerwcu 1948 r., i została bardzo wysoko oceniona przez uczestników (m.in. przez prof. Grzybowskiego). Po przejściu na emeryturę w 1990 r. prof. Jabłońska przez wiele lat była nadal związana z Kliniką. Prowadziła bardzo aktywnie badania naukowe, zawsze chętnie konsultowała trudne przypadki i preparaty histopatologiczne, służyła radą i pomocą wszystkim, którzy tego potrzebowali.

Profesor Stefania Jabłońska miała dwie wielkie pasje - dermatologię i naukę - i przez całe swoje życie konsekwentnie je realizowała. Pod jej kierownictwem warszawska Klinika rozwijała się bardzo dynamicznie. Powstał zgrany zespół zainteresowany zarówno dermatologią kliniczną, jak i pracą naukową (ryc. 1). Ważną rolę edukacyjną spełniały codzienne konsultacje kliniczne prowadzone przez prof. Jabłońską, w których uczestniczyli zarówno asystenci, jak i lekarze z innych placówek dermatologicznych (ryc. 2). Podczas konsultacji (i nie tylko) mogliśmy korzystać z ogromnej wiedzy i doświadczenia Pani Profesor, która zawsze powtarzała, że nie należy się wstydzić pytać nawet o rzeczy oczywiste, natomiast błędem jest brak wątpliwości i myślenie, że wie się wszystko. Profesor uczyła nas nie tylko książkowej dermatologii, lecz przede wszystkim umiejętności 


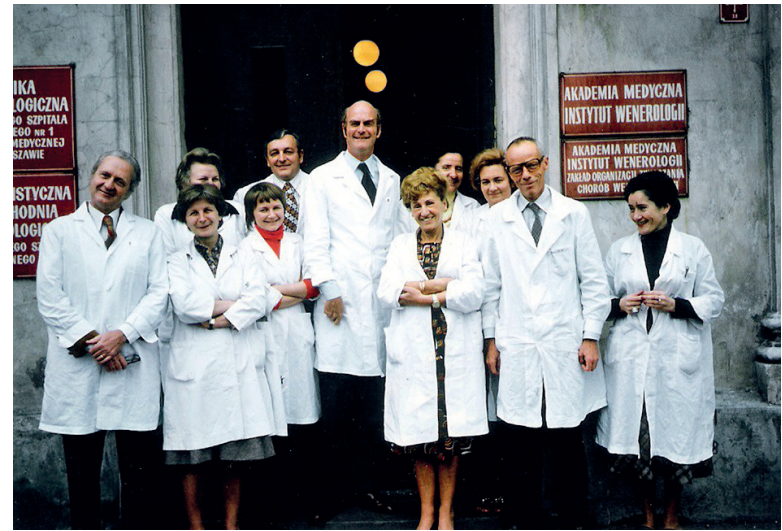

Rycina I. Profesor S. Jabłońska i zespół Kliniki z prof. N. Rowellem (Wielka Brytania)

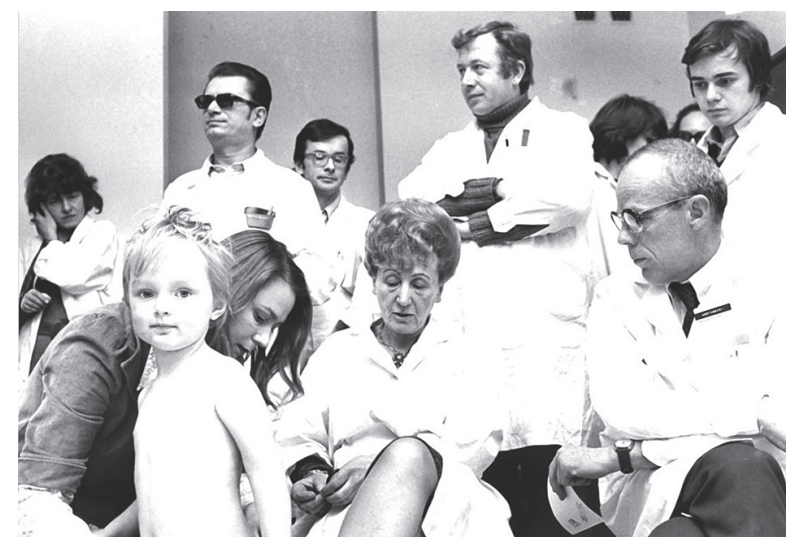

Rycina 2. Podczas konsultacji

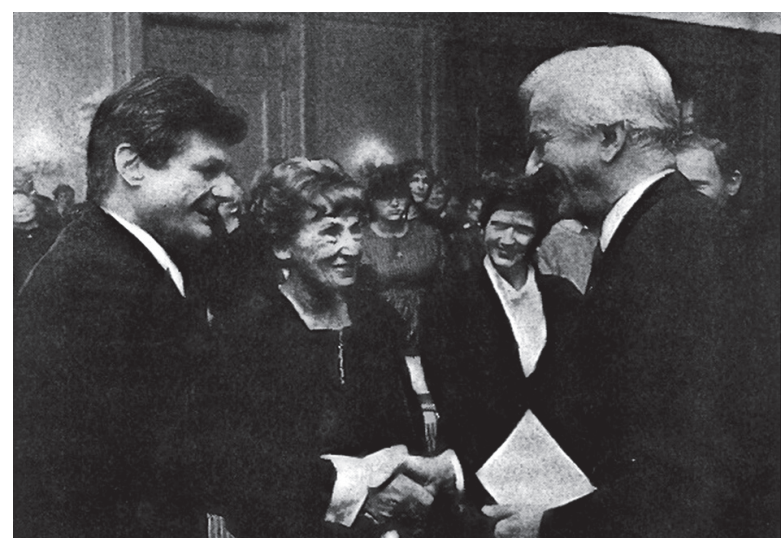

Rycina 3. Profesor S. Jabłońska i prof. G. Orth odbierają Nagrodę Roberta Kocha

patrzenia na skórę i poszukiwania związków zmian skórnych z chorobami narządów wewnętrznych, których wykrycie mogło przyspieszyć rozpoznanie choroby ogólnoustrojowej i przedłużyć, a nawet uratować życie chorego. Niezwykle ważna była wiedza prof. Jabłońskiej w dziedzinie histopatologii skóry. Jednoczesna świetna znajomość kliniki i histopatologii pozwalała jej na lepsze poznanie mechanizmów patogenetycznych choroby i stosowanie odpowiedniego leczenia. Dzięki znajomości języków (angielski, niemiecki, francuski i rosyjski) prof. Jabłońska była zawsze na bieżąco z osiągnięciami dermatologii światowej i wprowadzała - w miarę możliwości - do polskiej dermatologii nowoczesne metody badań i nowe terapie. Jako kierownik Kliniki zachęcała nas do pracy naukowej, podsuwała tematy, sugerowała pewne problemy i sposoby ich rozwiązania, ale przede wszystkim starała się nauczyć nas samodzielnego myślenia, interpretowania wyników badań i wyciągania wniosków. Była dumna z osiągnięć naukowych swojego zespołu i promowała je na konferencjach i zjazdach naukowych w Europie i Ameryce.

Profesor Stefania Jabłońska była promotorem 69 prac doktorskich i opiekunem 24 habilitacji, autorem lub współautorem 1009 prac naukowych, w większości publikowanych w liczących się czasopismach anglojęzycznych, oraz kilku monografii, a z jej podręczników („Choroby skóry dla lekarzy” oraz „Choroby skóry dla studentów”), które były wielokrotnie wznawiane, uczyło się kilka pokoleń lekarzy.

Swoją drugą pasję - naukę - prof. Jabłońska zaczęła realizować od samego początku pracy lekarskiej, początkowo pod kierunkiem prof. M. Grzybowskiego, który bardzo cenił swoją młodą asystentkę, a następnie już samodzielnie. Zagadnieniem, którym prof. Jabłońska zajęła się już pod koniec lat 50. ubiegłego wieku, w 1957 r., była rola wirusów w skórnej kancerogenezie.

Jako pierwsza na świecie, już w 1972 r., sformułowała hipotezę o onkogennym działaniu wirusów brodawczaka u chorych z rzadką chorobą genetyczną - epidermodysplasia verruciformis (EV), w której zmiany brodawkowate przekształcają się w raki skóry. We współpracy z prof. Gerardem Orthem z Instytutu Pasteura w Paryżu scharakteryzowała molekularnie pierwsze onkogenne wirusy oraz wykazała, że zakażenie tymi wirusami nie przenosi się na osoby zdrowe o innym układzie genetycznym. W ten sposób uzyskano dowód, że raki skóry mogą być uwarunkowane genetycznie, co zostało później potwierdzone wykryciem u chorych z EV mutacji nowych genów (EVER). Za prace nad EV prof. Jabłońska i prof. Orth otrzymali prestiżową Nagrodę Roberta Kocha, wręczoną w 1985 r. na uroczystym posiedzeniu przez prezydenta Niemiec Richarda von Weizsäckera (ryc. 3).

Drugim, niezwykle ważnym tematem badań naukowych prof. Jabłońskiej były choroby tkanki łącznej. Główne osiągnięcia w tej dziedzinie to charakterystyka odmian twardziny skórnej i układowej oraz opracowanie dużego działu chorób rzekomotwardzinowych o różnej etiologii i patogenezie. Badania te postawiły prof. Jabłońską w gronie ekspertów zajmujących się tą problematyką, a wydana w 1975 r. monografia "Scleroderma and Pseudoscleroderma” jest do dziś uważana za najlepsze i najpełniejsze opracowanie tych zagadnień. 
Odrębną dziedziną badań naukowych były autoimmunologiczne choroby peccherzowe. Prace te, prowadzone wspólnie z prof. Tadeuszem Chorzelskim (ryc. 4) i prof. Ernstem H. Beutnerem (Buffalo, USA), zaowocowały wprowadzeniem badań immunopatologicznych do diagnostyki chorób pęcherzowych, a także scharakteryzowaniem nowych jednostek chorobowych z ich kręgu (LABD, pęcherzyca opryszczkowata i inne).

W badaniach naukowych prof. Jabłońskiej znalazła swoje miejsce również łuszczyca. W pracach prowadzonych w Klinice warszawskiej wykazano rolę leukocytów wielojądrzastych i odczynowości komórkowej w patogenezie tej choroby.

Poza pracą dydaktyczną i naukową prof. Jabłońska aktywnie działała w Polskim Towarzystwie Dermatologicznym. Przez 30 lat (1961-1984 oraz 1989-1995) była prezesem PTD i w tym okresie Towarzystwo rozwijało się niezwykle dynamicznie - powstawały nowe sekcje, m.in. alergologii, immunopatologii, Forum Młodych (ryc. 5), stale zwiększała się liczba członków PTD, organizowano liczne zjazdy i konferencje naukowe $\mathrm{z}$ udziałem gości z zagranicy, a polscy dermatolodzy wyjeżdżali na kongresy i szkolenia zarówno do krajów europejskich, jak i za ocean.

Wyniki badań naukowych prof. Jabłońskiej oraz jej wiedza i poparta olbrzymim doświadczeniem znajomość dermatologii klinicznej zyskały uznanie nie tylko polskich, lecz także światowych dermatologów, czego wyrazem było m.in. nadanie jej tytułu członka honorowego przez ponad 40 dermatologicznych towarzystw naukowych z całego świata, a także członkostwo w tak prestiżowych instytucjach, jak Niemiecka Akademia Nauk „Leopoldina” czy Królewska Belgijska Akademia Nauk. Profesor była zapraszana na wykłady do najlepszych ośrodków dermatologicznych w Europie i Ameryce, uczestniczyła w licznych zjazdach i konferencjach naukowych, a w 1962 r. została po raz pierwszy wybrana jako jedyny przedstawiciel krajów Europy Wschodniej i jedyna kobieta do 12-osobowego Komitetu Wykonawczego Międzynarodowej Ligi Towarzystw Dermatologicznych i przez 20 lat była jej członkiem z wyboru (ryc. 6). Dzięki międzynarodowej pozycji prof. Jabłońskiej do Polski przyjeżdżali światowej sławy dermatolodzy, a jej nazwisko otwierało polskim dermatologom drzwi do najlepszych ośrodków dermatologicznych w Europie i Ameryce.

Międzynarodowa pozycja polskiej dermatologii jest nierozerwalnie związana z osobą prof. Jabłońskiej. To dzięki jej wiedzy, doświadczeniu klinicznemu i pasji naukowej wprowadzono nowoczesne kierunki i metody, a wyniki badań wykonywanych w polskich klinikach zyskały szerokie uznanie na świecie - tak powstała znana i ceniona polska szkoła dermatologiczna.

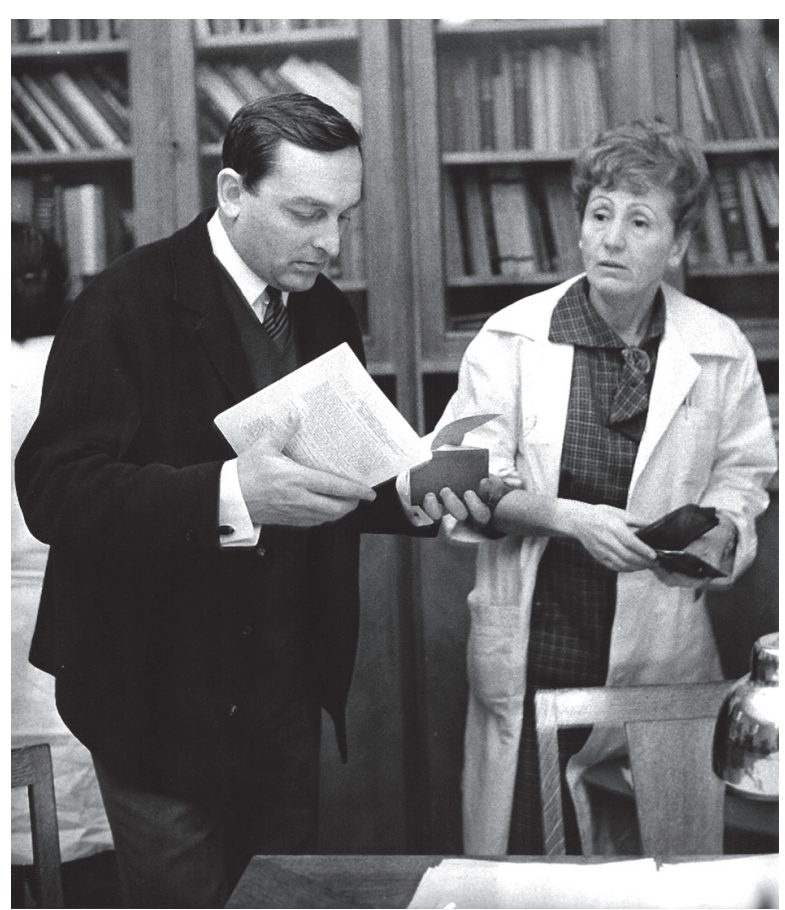

Rycina 4. Profesor S. Jabłońska podczas wspólnej pracy z prof. T. Chorzelskim

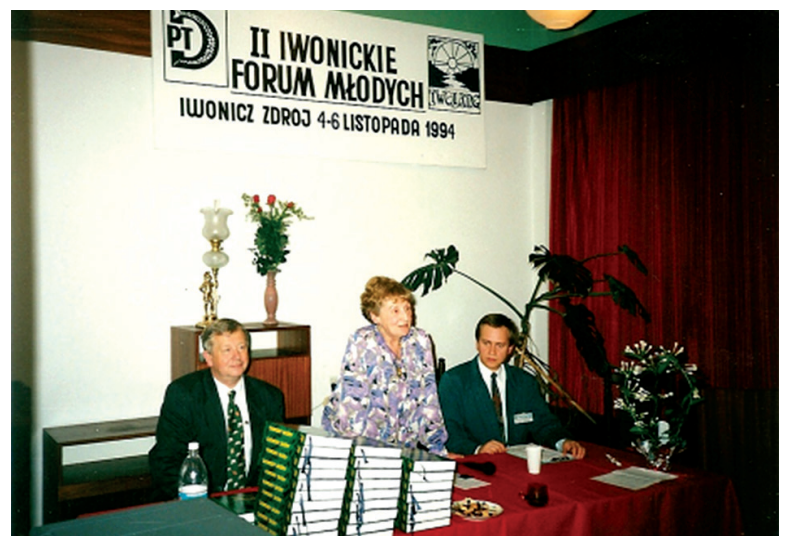

Rycina 5. Profesor S. Jabłońska przewodniczy sesji na konferencji Forum Młodych, z lewej prof. A. Langner, inicjator stworzenia Forum, z prawej prof. S. Majewski

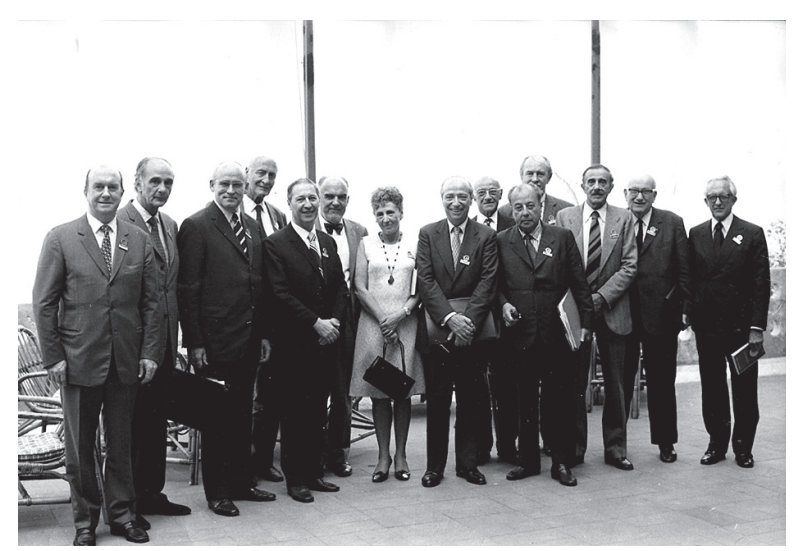

Rycina 6. Komitet Wykonawczy Międzynarodowej Ligi Towarzystw Dermatologicznych 


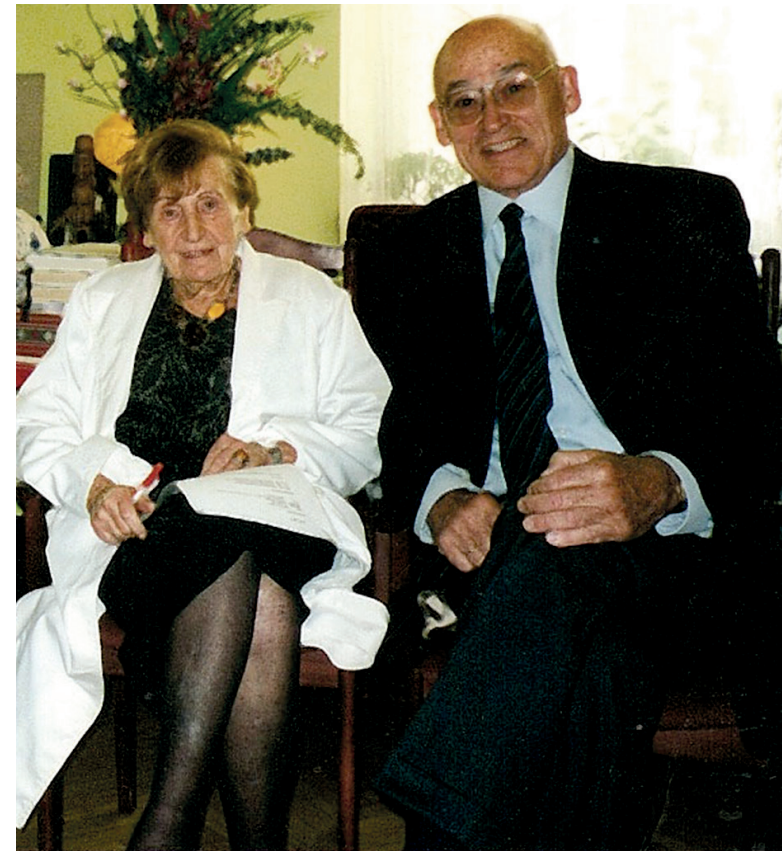

Rycina 7. Profesor Stefania Jabłońska i prof. Otto Braun-Falco

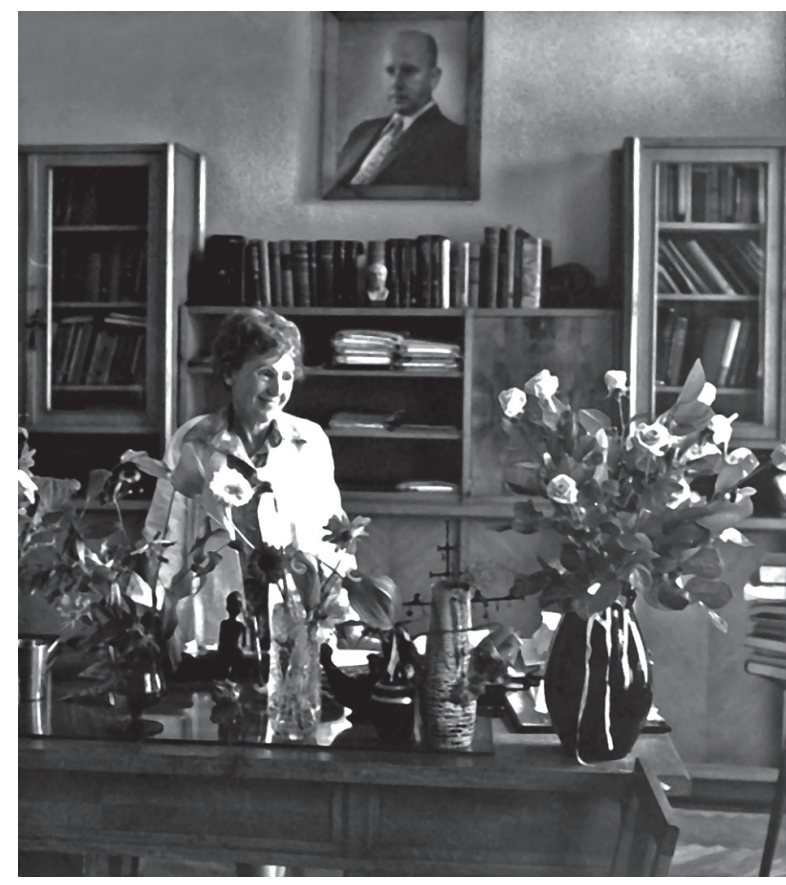

Rycina 8. Kilka dni po imieninach
Profesor Jabłońska prowadziła współpracę naukową z wieloma placówkami, ale za najważniejszą dla rozwoju polskiej dermatologii uważała współpracę polsko-niemiecką zapoczątkowaną w 1956 r. przez prof. Alfreda Marchioniniego, kierownika Kliniki Dermatologicznej w Monachium. Współpraca ta rozwijała się bez żadnych formalnych umów. Młodzi dermatolodzy z różnych polskich ośrodków wyjeżdżali na 6-miesięczne stypendia do Monachium, gdzie mieli dostęp do bibliotek, poznawali nowoczesne metody badań i mogli pracować naukowo. Po śmierci prof. Marchioniniego współpracę tę kontynuował prof. Otto Braun-Falco (ryc. 7).

Za swoją działalność naukową i lekarską prof. Stefania Jabłońska została uhonorowana zarówno w Polsce, jak i za granicą licznymi odznaczeniami i nagrodami, m.in. Polskiej Akademii Nauk, wpisaniem w 2006 r. do Złotej Księgi Nauki Polskiej, a w 2010 r. do Złotej Księgi Nauk Medycznych. Lista międzynarodowych medali i odznaczeń jest bardzo długa, ale za najważniejsze sama Pani Profesor uważała Złoty Medal Alfreda Marchioniniego i Nagrodę Roberta Kocha.

Profesor Jabłońska była osobą niezwykle zapracowaną, żyła w ciągłym pośpiechu, ale pomimo to znajdowała czas na teatr czy dobry lub kontrowersyjny film, dużo czytała - nie tylko literaturę fachową, lecz także beletrystykę, śledziła wydarzenia polityczne w Polsce i za granica, lubiła spotkania towarzyskie, na których często była duszą towarzystwa. Szczególnym świętem był dzień imienin Pani Profesor. Przez Klinikę przewijało się wówczas mnóstwo mniej lub bardziej znanych osób, które przychodziły, aby okazać Jej swój szacunek, życzliwość, serdeczność i przyjaźń. Pani Profesor cieszyła się tym dniem, a jej gabinet tonął w kwiatach (ryc. 8).

Profesor Stefania Jabłońska interesowała się życiem swoich współpracowników, przeżywała wspólnie z nimi dobre i złe chwile, była osobą bliską, a dla części z nas prawdziwym przyjacielem.

Odejście prof. Stefanii Jabłońskiej zakończyło ważny rozdział w naszym życiu, ale pamięć o Niej pozostanie $\mathrm{z}$ nami na zawsze.

prof. dr hab. n. med. Maria Błaszczyk prof. dr hab. n. med. Sławomir Majewski 